\title{
Methodical approaches to economic assessment of farming system efficiency taking into account quality of the land resources
}

\author{
Klavdia Churilova ${ }^{1, *}$ and Elena Volkova $^{1}$ \\ ${ }^{1}$ Far Eastern State Agrarian University, Blagoveshchensk, Amur Region, Russia
}

\begin{abstract}
The existing methodical approaches to the assessment of the farming system efficiency and agricultural lands are based on the physical hectares not taking into account quality of the plots, and thus it distorts the reliability of the calculation of indices. The existing methods of determination of cadastral price of the agricultural lands comprise the variety of qualitative indicators. In connection with this we suggest the methods of assessment of the farming system efficiency in accordance with the output factors per 1 ruble of cadastral value of the agricultural lands: gross (commodity) output of crop production (technologic efficiency coefficient of land resources); income of production and realization of crop production and animal husbandry products with and without state support (land resources net profit ratio with and without state support), level of state support efficiency. For comparison, the index method is used. The researches prove that indices taking into account cadastral assessment of land resources differ from indices calculated in accordance with physical values and allow judging of influence of land resources quality on technological as well as on economic result, and also assess comparative level and efficiency of state support rendered. The method implies carrying out comparative assessment of efficiency of developing and existing farming systems in regard to agricultural enterprises, regions, agricultural zones and also assessment of the level and efficiency of state support using indices of the cadastral assessment.
\end{abstract}

\section{Introduction}

In agriculture, production is related to the quality of the land, the nature and conditions of its use. The task of the land user is to make the most complete and rational use of the natural and economic fertility of the land, the latest achievements of science and technology in order to obtain the potential yield of all crops at the lowest cost per unit of production.

Land in agriculture acts as a natural resource and a natural object at the same time, is the main means of production, the spatial basis for activities, acts as a capital asset, and has unique properties characterized by soil fertility. The uniqueness of land is that it can not be replaced by any other resource, it is limited within the economic supply. In modern conditions of business activity of agricultural organizations, the use of resources should be con-

\footnotetext{
* Corresponding author: klava.churilova@mail.ru
} 
sidered through the prism of value creation as a system that determines the existence of an economic entity in the present time, its strategic and tactical development in the future. The internal essence of the value creation system is revealed through the structure of business processes - a stable and interconnected set of activities that use resources, technologies and create products that represent value. This approach should be used when evaluating the effectiveness of land use as the main and specific resource of agricultural production [10].

In modern conditions of business activity of agricultural organizations, the use of resources should be considered through the prism of value creation as a system that determines the existence of an economic entity in the present time, its strategic and tactical development in the future. The internal essence of the value creation system is revealed through the structure of business processes - a stable and interconnected set of activities that use resources, technologies and create products that represent value. This approach should be used when evaluating the effectiveness of land use as the main and specific resource of agricultural production [10].

The economic efficiency of land use is characterized by the level of production of agricultural products - the higher the volume of production while reducing the cost of labor and means of production, the higher the economic efficiency of the use of land resources. The economic efficiency of land use is expressed by a number of indicators that can be divided into three groups: natural, cost and relative (Fig.1).

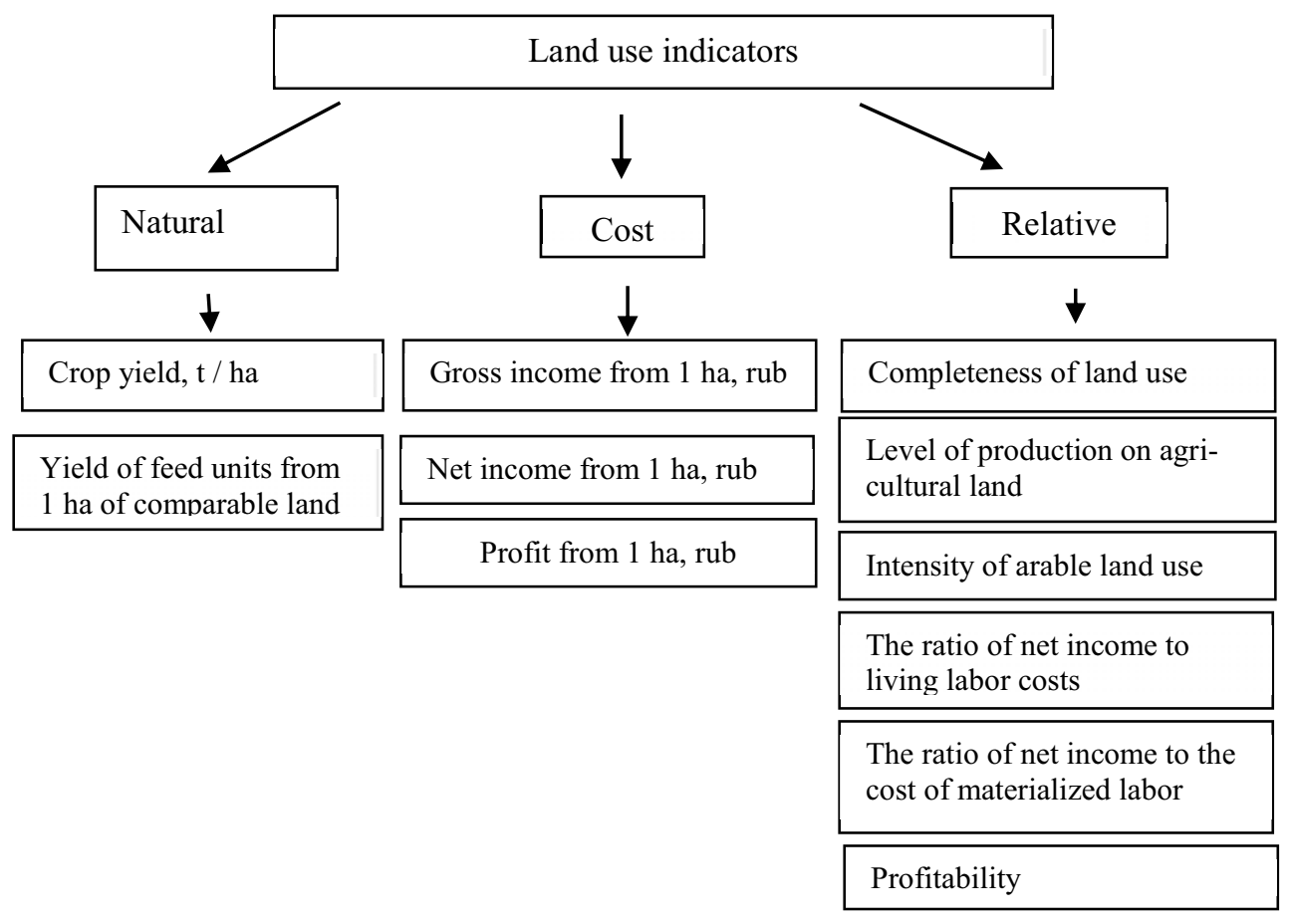

Fig. 1. Land use Indicators [1].

The efficiency of land use is characterized by a relatively small number of indicators that are influenced by a whole system of factors. Factors are elements or causes that affect a given indicator or a set of indicators. The difference between the concepts of "indicator" and" factor " is conditional, since almost every indicator can itself be considered as a factor of another indicator of a higher order and Vice versa. From objectively determined factors, 
it is necessary to distinguish subjective ways of influencing indicators, i.e. possible organizational and technical measures that can influence the factors that determine this indicator

The classification of factors allows us to clarify the relationship between the characteristics that affect efficiency, to approach the problem of evaluating and changing the efficiency of production. Factors in economic analysis can be classified by various criteria. For example, factors may be General, i.e. they affect a number of indicators, or particular, specific to this indicator. The generalization of many factors is explained by the relationship and mutual conditionality that exist between individual indicators.

Among the factors that have the greatest impact on the efficiency of land use, the following should be noted: the share of arable land in the total area of land; the share of reclaimed land; the share of crops sown using intensive technologies; natural climatic conditions; soil fertility; the amount of mineral and organic fertilizers applied per 1 ha of agricultural land [1].

In modern conditions, an important point is the fact that the land is not only the sphere of application of the crop industry, but also closely linked to the development of animal husbandry. Therefore, the evaluation of the efficiency of land resources should include indicators of the efficiency of crop production as a basic industry, but also the effectiveness of livestock production in terms of economic efficiency.

The efficiency of land use involves the development of farming systems and the evaluation of its effectiveness.

Performance criteria and its system of indicators are an indicator of profitability of production activities. In relation to agricultural land resources, efficiency is considered not only in terms of increasing production volumes, improving its quality, reducing unit costs, but also preserving or improving the quality characteristics of the land (soil fertility), as well as ensuring environmentally safe production. This approach is due to the specifics of agricultural activity, which combines the processes of reproduction of land resources and production of agricultural products [10].

The modern system of agriculture - a scientifically-based set of methods of production of crop production and forms of rational use of agricultural landscapes and resource and energy potential of the economy, reproduction of fertility and conservation of ecological balance, is one of the main factors of efficiency of the agro-industrial complex [11].

The choice of a rational farming system is based on a comprehensive assessment of its effectiveness.

The study of methodological approaches to assessing the effectiveness of crop production has shown that most authors emphasize the assessment of the system of technological and economic indicators without taking into account the quality of land plots where agricultural crops were produced [2, 3, 4].

Khairulina O. I. Developed an assessment of the effectiveness of reproductive processes in plant production. It is proposed to classify factors that affect the reproduction process into the following components: technological, economic, social, organizational and environmental. Economic assessment assumes specific indicators-cost price, profitability by product type, production costs per 1 ruble of produced (sold) products; General - production of crop production per 100 hectares of arable land (agricultural land). The method involves evaluating each factor in points. However, the qualitative assessment of agricultural land is not linked [12].

The academic literature reflects the main indicators of land use efficiency - land yield, land intensity, volume of production of gross (commodity) products, gross and net income, profit per 1 ha of land area, as well as crop productivity [7]. The authors do not take into account the quality of land resources.

Attempts are made to link methodically the assessment of the economic assessment of land use, taking into account the variety of soil qualities of the land and allowing for a more 
objective level to determine the effectiveness in accordance with the actual economic conditions of the producer. However, the mechanism and specific indicators linked to the quality of land resources are not provided [13,8].

Various approaches to land use assessment have been repeatedly considered in the economic literature. In particular, there were attempts to find a General indicator (index) that would make it possible to simultaneously determine the economic efficiency of land use and the level of development of the economy as a whole. But, often, these indicators were very conditional in nature, practically giving no idea of the degree of use of land, material and labor resources. Some suggested evaluating the economic efficiency of land use by private indicators: gross income, net income, profit per unit of land area, gross output in monetary terms, and other indicators. However, since the productive properties of the land are activated by living and past labor and are manifested in the products produced, our research has shown that it is practically impossible to directly divide the result according to the factors of production, since the production process itself is carried out only if all of them are present in concrete proportions. Therefore, a system of indicators is often used for a comprehensive assessment of land use. The most common is the system of factorial and performance indicators. This system was formed in the pre-reform period, and over time it was supplemented and updated with new indicators [13].

E. Yu. Merkulov, G. B., and elms form the portrait of the clusters by the distribution of land resources in the region, including agricultural land, suggest a method to assess efficiency of land use of the region containing complex structural rating categories of land resources. As an indicator of the efficiency of agricultural land use, the volume of production in relation to the area of agricultural land (RUB/ha) is proposed [6].

Specific natural conditions make it necessary to study the issues of land management and land use more carefully. Reforms carried out in the agricultural sector will not produce positive results if consistent policy measures supported by the state are not implemented in land use.

The organization of agricultural production requires accurate data on the state of land fertility, and then on the crops grown. To do this, it is necessary to have a unified system of land accounting and assessment in the country and Republic.

Previously, information about land was limited to the registration of land users and quantitative accounting of land, which provided for the need for society to legally formalize the right to perpetual ownership and use of land and record them by the composition of land, in the context of land users. However, the quality of the land was not taken into account.

Solving the problems of effective land use today requires the organization of accounting and evaluation of specific conditions of agricultural production for a separately cultivated area. It is known that even within the same farm, and even more so within the district, there are lands that significantly differ in natural and economic fertility, which affects the results of production [13].

\section{Materials and methods}

An important role in the effective use of natural resources is assigned to the cadastre - a systematized set of documented information about the natural, economic and legal status of land. Decree of the Ministry of economic development of the Russian Federation No. 445 of 20.09.2010 approved methodological recommendations for the state cadastral assessment of agricultural land. In accordance with the methodology (paragraph 2.2.2), the list of soil varieties, the list of crops, and the standard yield of each crop are determined on the basis of soil surveys and materials of agro-climatic zoning of the territory of the subject of the Russian Federation. 
Therefore, when determining the cadastral price, qualitative indicators of land resources are taken into account and reflected. Based on this methodology, the results of the state cadastral assessment of agricultural land were carried out and approved in the Russian regions, as well as specific indicators of the cadastral value of agricultural land by groups of types of their functional purpose in accordance with the cadastral number, on the territory of municipal districts and in the region as a whole, according to quality indicators.

\section{Results}

Calculation of the specific indicator of cadastral cost of lands in the land as srednevo-high area soil types of specific indicators of cadastral cost of plots can be calculated for individual agricultural enterprises and groups of enterprises, municipalities and agricultural areas.

The weighted average cadastral value of a group of plots $(\bar{K})$ is determined using the formula:

$$
\bar{K}=\frac{\sum_{i=1}^{n} S i * k i}{\sum_{i=1}^{n} S i}
$$

where, $S i$ - area of the I-th enterprise, district, hectare;

$k i$ - indicator of the cadastral value of $1 \mathrm{sq}$. $\mathrm{m}$, rubles of the I-th plot.

When assessing the economic efficiency of the farming system, it is necessary to determine the system of indicators of assessment.

Since forage crops do not have a commodity component and realize their potential in the produced and sold livestock products, we consider it appropriate to conduct a two-level assessment of the economic efficiency of the farming system:

1) technological efficiency of crop production;

2) economic efficiency of agriculture, including crop and livestock production.

At the first level, a summary measure of technical efficiency of crop production OSnovynette on gross crop production taking into account quality of land resources and is expressed in gross output (product) of crop production per 1 ruble of the cadastral value of agricultural land, rubles and is expressed by the coefficient of technical efficiency of land resources, taking into account their quality.

The indicator is calculated using data from the object being evaluated:

1. Weighted average cadastral value of agricultural land $(\bar{K})$, rubles per 1 hectare of a region, municipal district, group of municipal districts, or agricultural enterprise according to the formula (1).

2. Weighted average output of gross (commodity) crop production per 1 ha of agricultural land $\left(\overline{\dot{W}}_{S}\right)$, determined by the formula:

$$
\overline{\mathrm{W}}_{\mathrm{S}}=\frac{\sum_{i=1}^{n} W i}{\sum_{i=1}^{n} S i}
$$

where $\mathrm{Wi}-$ the cost of gross (commodity) crop production of the i-th object, rubles; $\mathrm{Si}$ - area of agricultural land of the i-th object. 
3. Weighted average output of gross (commodity) crop production per 1 ruble of cadastral value $\left(\overline{\dot{W}}_{\kappa}\right)$, determined by the formula:

$$
\overline{\mathrm{W}} \kappa=\frac{\sum_{i=1}^{n} W i}{\bar{K}}
$$

4. The coefficient of technical efficiency of land resources $(\mathrm{Zt})$ is calculated according to the formula:

$$
Z t=\frac{\bar{W}}{\bar{K}}
$$

The efficiency of land use is more fully determined by indicators of economic efficiency of agriculture, including crop and livestock production.

At the second level, the aggregate indicator of economic efficiency of agriculture is based on the output of net profit per 1 ruble of the cadastral value of land resources. In terms of economic content, the proposed indicator reflects the profitability of land resources and is expressed by the coefficient of profitability of land resources, taking into account their quality. It is important to take into account the impact of government support measures.

The object of evaluation is identified:

1) area of agricultural land, arable land, hectare;

2) weighted average value of commodity products;

3) weighted average cadastral value of land resources, rubles;

4) net profit taking into account the state support rubles;

5) net profit excluding state support, rubles.

The indicator is calculated using data from the object being evaluated:

1. weighted Average yield of commercial agricultural products $(\bar{T})$ per 1 ha of agricultural land in the region of the object of assessment.

$$
\bar{T}=\frac{\sum_{i=1}^{n} T i}{\sum_{i=1}^{n} S i}
$$

where $\mathrm{Ti}-$ the cost of commercial crop and livestock products of the i-th object, rubles;

$\mathrm{Si}$ - area of agricultural land of the i-th object, hectare.

2. The weighted average yield of net profit taking into account the state $(\mathrm{P} \bar{n})$ per 1 ha of agricultural land, rubles.

$$
P \bar{n}=\frac{\sum_{i=1}^{n} P n i}{\sum_{i=1}^{n} S i}
$$

where Pni - net profit including state support for the i-th object, rubles;

$\mathrm{Si}-$ area of agricultural land of the i-th object.

3. Weighted average of net profit output excluding state support $(P \bar{p})$ per 1 ha of agricultural land, rubles. 


$$
P \bar{p}=\frac{\sum_{i=1}^{n} P p i}{\sum_{i=1}^{n} S i}
$$

where Ppi - net profit excluding state support for the i-th object, rubles;

$\mathrm{Si}$ - area of agricultural land of the i-th object, hectare.

4. Received net profit per 1 ruble cadastral value of agricultural land - the coefficient of profitability of land resources, taking into account state support $(R n)$ :

$$
R n=\frac{P n k}{K}
$$

where Pnk - the profit taking into account the state support rubles;

$\mathrm{K}$ - cadastral value of the $\mathrm{i}$-th object, rubles.

5. Received net profit per 1 ruble cadastral value of agricultural land - the coefficient of profitability of land resources without state support (Rp), rubles:

$$
R p=\frac{P p k}{K}
$$

where Rrk - profit received without state support, rubles;

$\mathrm{K}$ - cadastral value of the I-th object, rubles [14].

For a comparative assessment of the efficiency of farming systems and land use, it is advisable to use the index method [5]. The indicator for the region is taken as the base for comparing General indices, while the southern zone is used for comparing agricultural zones. Comparison indices with the basis characterize the level of efficiency of the object in comparison with the basic one. The excess of the index of the level of return reflects the excess of the index over the compared indicator. Comparison of indicators of technological and economic efficiency by physical indicators and taking into account the quality of land resources indicates that the quality potential of soils in the southern zone is underutilized and the level of technological and economic efficiency of the current farming system is lower than in the Central and Northern zones [14].

\section{Discussion}

In our opinion, when comparing the efficiency of agricultural land in the region by its structural units, it is necessary to take into account the quality of land resources. In the opposite case, natural soil fertility and climatic features that affect crop productivity are not taken into account. This also distorts the comparative assessment of the effectiveness of land resources, agricultural systems, and measures of state support for crop production in zones with different quality of land resources.

Thus, in a market economy, economic indicators of land use efficiency come to the fore, without detracting from the importance of technological, environmental and social efficiency. The proposed methods for assessing the economic efficiency of land use, farming systems, and crop production as the basis of agriculture (agricultural production) do not provide a mechanism for accounting for the quality of land resources that affect the effectiveness of human activities and ensure the accuracy of calculating indicators based on modern databases. This indicates the relevance of the proposed methodology for evaluating the effectiveness of the farming system, taking into account the quality of land resources. 


\section{Conclusions}

Thus, the method involves a comparative assessment of the effectiveness of the developed, operating systems of agriculture for agricultural enterprises, regions, agricultural zones by indicators of the coefficient of technological efficiency and the coefficient of profitability of land resources, taking into account state support and without state support. As well as evaluating the level and effectiveness of state support, taking into account the quality of agricultural land resources, taking into account the indicators of cadastral assessment.

\section{Reference}

1. L. B. Vinnichek, V. N. Yashkina, I. V. Yashkina Efficiency of land resources use in the Republic of Mordovia)

2. A. Kalinina, L. Pushkareva, A. Rybakova, National Identity of Mass Media: Retrospective Study of the Russian Language Mass Media Prevalence in Eastern Europe, Amazonia Investiga 8(22), 40-50 (2019)

3. Strielkowski W, et al. Innovative Policies for Energy Efficiency and the Use of Renewables in Households Energies 12(7), 1392 (2019) doi:10.3390/en12071392

4. A.R. Latypov Biznes v zakone (Business in law), Ekonomiko-yuridicheskii zhurnal, 6, 135-138 (2012)

5. O.E. Luginin, Statistika v rynochnoi ekonomike (Statistics in a market economy), 505 (2006)

6. E.Yu. Merkulova, G.B. Vyazov, Metodika otsenki effektivnosti ispol'zovaniya zemel'nykh resursov regiona (The technique of an estimation of the efficiency of use of the land resources of the region), Vestnik Tambovskogo universiteta. Ser.: Gumanitarnye nauki, 2 (142), 55-65 (2015)

7. I.A. Minakov, Ekonomika sel'skogo khozyaistva. Uchebnik 229 (2015)

8. I.S. Sandu, V.A. Svobodina, , V.I. Nechaev, Effektivnost' sel'skokhozyaistvennogo proizvodstva. Metodicheskie rekomendatsii (The efficiency of agricultural production. Guidelines), 228 (2013)

9. Sistema zemledeliya Amurskoi oblasti (The farming system of the Amur region), Proizvodstvenno-prakticheskii spravochnik pod obshchei redaktsiei Tikhonchuka P.V., Izd-vo Dal'nevostochnogo GAU, 570 (2016)

10. M. A. Stolyarova, O. V. Zherdeva Methodological aspects of effectivtness of use of land resources of agricultural purposes, The scientific journal of the Kuban state agrarian University, 96(02), (2014)

11. P.V. Tikhonchuk, O.V. Shchegorets, Sistema zemledeliya Amurskoi oblasti: problemy i puti resheniya (The farming system of the Amur region: problems and solutions), Dal'nevostochnyi agrarnyi vestnik, 3 (39), 130-139 (2016)

12. O.I. Khairulina, Metodicheskie aspekty ekonomicheskoi effektivnosti vosproizvodstvennykh protsessov $\mathrm{v}$ rastenievodstve (Methodological aspects of economic efficiency of reproduction processes in crop production), Vestnik Altaiskogo gosudarstvennogo agrarnogo universiteta, 5 (115), 186-191 (2014)

13. T.G. Khanbabaev, G.D. Dogeev Otsenka effektivnosti ispol'zovaniya zemel' sel'skokhozyaistvennogo naznacheniya (The assessment of the efficiency of use of agricultural land), Mezhdunarodnyi nauchno-issledovatel'skii zhurnal, 9 (40), 70-73 (2015) 
14. K.S Churilova, P.V. Tikhonchuk, E.A.Volkova, Metodika ekonomicheskoi otsenki sistemy zemledeliya s uchetom kachestva zemel'nykh resursov (The methodology of economic evaluation of farming systems, taking into account the quality of land resources), Izd-vo Dal'nevostochnogo GAU (2017)

15. L. Pushkareva, M. Pushkarev Innovative activity and some features of taxation E3S Web of Conferences 164, 10027 (2020) doi:10.1051/e3sconf/202016410027 